\title{
Implementation Of Individual Guidance Through Whatsapp Group To Increase Achievement And Learning Motivation Of Students Of Class VII Smp Negeri 3 Ngaglik Sleman 2020/2021
}

\author{
Suratmi ${ }^{a}$ * \\ a SMP Negeri 3 Ngaglik Sleman D.I Yogyakarta \\ *Corresponding author: suratminganglik@gmail.com
}

Received: August 30, 2021; Accepted: October 4, 2021; Published: October 15, 2021

\begin{abstract}
This study aims to increase the learning motivation of seventh grade students of SMP Negeri 3 Ngaglik Sleman through "WhatsApp Group" in individual guidance. The population in this study were 369 students. The sample in this study was class VII SMP Negeri 3 Ngaglik Sleman totaling 128 which was divided into 3. The research method used in this study was Action research Guidance Counseling with the model developed by Kemmis and Mc. Taggart goes through four stages, namely planning, action, observation, and reflection. The research flow is carried out in two cycles. The results showed that the application of individual guidance through WhatsApp Group to the learning outcomes of Class VII students of SMP Negeri Ngaglik Sleman could increase. The average student evaluation results have exceeded the minimum value for each subject. As for the results after the students carried out mentoring activities for 3 cycles, as many as 5 students were in the very good category, and as many as 25 students were in the good category, and in the sufficient category as many as 2 students. Overall, the development of learning outcomes before being given action (pre-action) and after being given action for 3 cycles increased by $93.75 \%$. Based on the results of the study showed that as much as $85 \%$ in the process of applying individual guidance through "WhatsApp group" on learning motivation can be used as an alternative in an effort to improve the process and learning outcomes of students..
\end{abstract}

Keywords: Individual Guidance, WhatsApp Group, Learning Motivation

\section{INTRODUCTION}

Education has an important role in the development of one's personality, in accordance with the Law of the Republic of Indonesia Number 20 of 2003 which states that education creates potential in oneself in the form of religious spiritual strength, self-control, personality, intelligence, noble character, and skills needed to be able to live. in the community with a conscious and planned effort. Therefore, to get intelligence, it is necessary to study. Learning is a system that is contained in the learning process, which consists of several components that interact with each other, consisting of: teachers, students, objectives, materials, media, methods, and evaluations.

There are various understandings of guidance put forward by experts that guidance is assistance given to individuals (students) so that with their potential they are able to develop themselves optimally by understanding themselves, understanding the environment, overcoming obstacles to determine better future plans [1]. Individual counseling, namely guidance and counseling services that allow students or counselees to get direct face-to-face services (individually) with the supervising teacher in the context of discussing alleviation of personal problems suffered by counseling.

Guidance through online, the selected media must meet the principles of online mentoring, meaning that the media used can be easily accessed by teachers and students so that good communication is established and the goals set can be achieved well even in remote conditions. Online tutoring can use 
digital technology such as google classroom, study house, zoom, video conference, telephone or live chat and others [2]. There are many media used for online tutoring, various platforms have long provided this service, such as Google Classroom, Learning House, Edmodo, Ruang Guru, Zenius, Google Suite for Education, Microsoft Office 365 for Education, Your School, Smart Class [3]. In addition, the use of WhatsApp is also an Instant Messaging application technology [4].

Guidance media has a very important role for the success of student learning. With the use of learning media, it will encourage the involvement of students in the learning process, and make it easier for students to understand the material being studied. In choosing media, it is very important to pay attention to factors, namely Access, Cost, Technology, Interactive Activity, Organizational change, Novelty, and Speed factors [5]. The use of media greatly influences the response of students, with the media the mentoring process will be more effective, active and creative and can foster student interest and motivation to learn. Therefore, the role of a counseling guidance teacher is currently very much needed, not only professional and competent in their field but able to increase their knowledge, master and develop media, and be able to increase learning motivation in accordance with competency standards, basic competencies and indicators.

WhatsApp social media is now widely used by various groups, especially students. WhatsApp as a chat application that can send text messages, pictures, sounds, locations and videos to other people using any type of smartphone [6]. WhatsApp Group applications usually use 3G/4G or WiFi connections for data communication. By using WhatsApp Groups, one can have online chats, share files, and exchange information [7]. WhatsApp Group is an Instant Messaging technology such as SMS with the help of internet data with more attractive supporting features and is the most popular social media that can be used as a communication medium. The WhatsApp Group application has the potential to be used as a learning tool [4].

WhatsApp media has several advantages. The advantages of WhatsApp Media are that it is easy to use, practical, quickly saves internet data, and can be accessed only with mobile phones, has various features that can be used to support communication, such as the New Group, New Broadcast, WhatsApp Web, Starred Messages and Settings with internet service assistance. The choice of group menus is used as a place to discuss teachers with students and students with their friends in solving problems, for example the teacher sends several problems to be solved according to the material that has been given, discusses, delivers material by the teacher, for example in the implementation of learning the teacher can convey material by sending teaching videos, in the form of photos or sound recordings. The use of WhatsApp is very helpful in communicating activities in distance learning in the midst of current conditions [8].

The use of WhatsApp Groups for learning media occurs at the school level. Of course, due to various considerations from surveys conducted by researchers, 100\% of online learning only uses WhatsApp group media [9]. The reason WhatsApp users choose this application is because of the availability of various conveniences that are in it at no cost [10]. The use of WhatsApp Groups as a mentoring medium occurs a lot in elementary and secondary schools. Of course, due to various considerations from surveys conducted by researchers, 100\% of online guidance only uses WhatsApp Group media [9]. The reason for using WhatsApp is because this application has various facilities in it and does not incur costs through WhatsApp Groups, it is hoped that students can improve learning outcomes and further student learning motivation.

Learning motivation is one of the factors that determine effectiveness in learning. A student will learn well if there is a motivating factor, namely learning motivation. Students will study seriously if they have high learning motivation. The motivation can be interpreted as a driving force that has become active. Motives become active at certain times, especially when the need to achieve goals is felt to be urgent [11].

Learning motivation is an internal and external encouragement for students who are learning to conduct behavior, in general with several indicators or supporting elements [12]. These indicators include: the desire and desire to succeed, encouragement and need for learning, hopes and aspirations for the future, appreciation in learning, and a conducive learning environment. Furthermore, the learning motivation is the overall psychic driving force in students that causes learning activities to achieve a goal [13]. The learning motivation is the entire driving force within students that causes learning activities that ensure the continuity of learning activities that provide direction to learning activities so that the goals desired by the learning subject can be achieved [14].

The year 2020 in the pandemic era is the toughest year for education units (teachers and counseling teachers) for various parts of the world, especially Indonesia. Coronavirus Diseases 2019 (COVID-19) is the name for a new virus given by the World Health Organization (WHO) that can spread quickly. On January 30, 2020 WHO has declared it a public health emergency that is troubling the world due to the 
spread of the corona virus. The corona virus outbreak has had a significant impact on various sectors, especially education.

The government through the minister of education provides a policy to stay at home by conducting online or online learning activities for all elementary, middle, high school and university students. In accordance with the Circular Letter of the ministry of education and culture Number 3 of 2020 on the Education unit through the Circular Letter of the Minister of Education and Culture Number; 36962/MPK. A/HK/2020 concerning "Online learning (On the Network) in order to prevent the spread of Corona Virus Diseases (COVID-19)" which states that all indoor and outdoor activities in all sectors are temporarily postponed in order to reduce the spread of corona, especially in the field of education. With the issuance of this circular, the learning process can be carried out online to provide a meaningful learning experience, provide a focus on life skills, as well as various learning activities according to the interests, conditions and facilities of students.

The role of guidance and counseling teachers in this Covid-19 pandemic era requires extra work to help students cope with learning by motivating students to further improve learning even though learning is done online. Learning media has a very important role for the success of individual guidance through online. the use of media will encourage the involvement of guidance teachers in the learning process, as well as provide motivation for students in learning in the era of the covid-19 pandemic. In selecting media, it is very important to pay attention to factors, namely Access, Cost, Technology, Interactivetivity, Organizational change, Novelty, and Speed factors [5].

In relation to the use of online mentoring media via WhatsApp at SMP Negeri 3 Ngaglik Sleman, the researchers intend to conduct research related to the use of WhatsApp Groups as online mentoring media during the Covid-19 Pandemic Period for class VII at SMP Negeri 3 Ngaglik Sleman.

In this study, we will examine the Application of Individual Guidance through Whatsapp Groups on Students' Learning Motivation in Class VII SMP Negeri 3 Ngaglik Sleman in 2020/2021 during the Covid19 Pandemic, how are the obstacles that occur in the use of WhatsApp Groups, as a medium of mentoring in the network as well as solutions to overcome obstacles in the implementation of online mentoring by utilizing WhatsApp groups at the school. The purpose of the study was to obtain accurate data and information related to the use of WhatsApp Group as a media for assistance in the network during the Covid-19 pandemic at SMP Negeri 3 Ngaglik Sleman.

\section{RESEARCH METHODOLOGY}

The method used in this research is Counseling Guidance Action Research. Guidance and counseling action research is pursued as well as classroom action research, carried out through an initial identification process/problem formulation and then a cyclical or cyclical assessment is carried out, which consists of four stages, namely: (1) planning, (2) implementing action. (3) observing, and (4) reflecting, then revising. Figure 1 shows the research flow that is used as a guide in this research. 


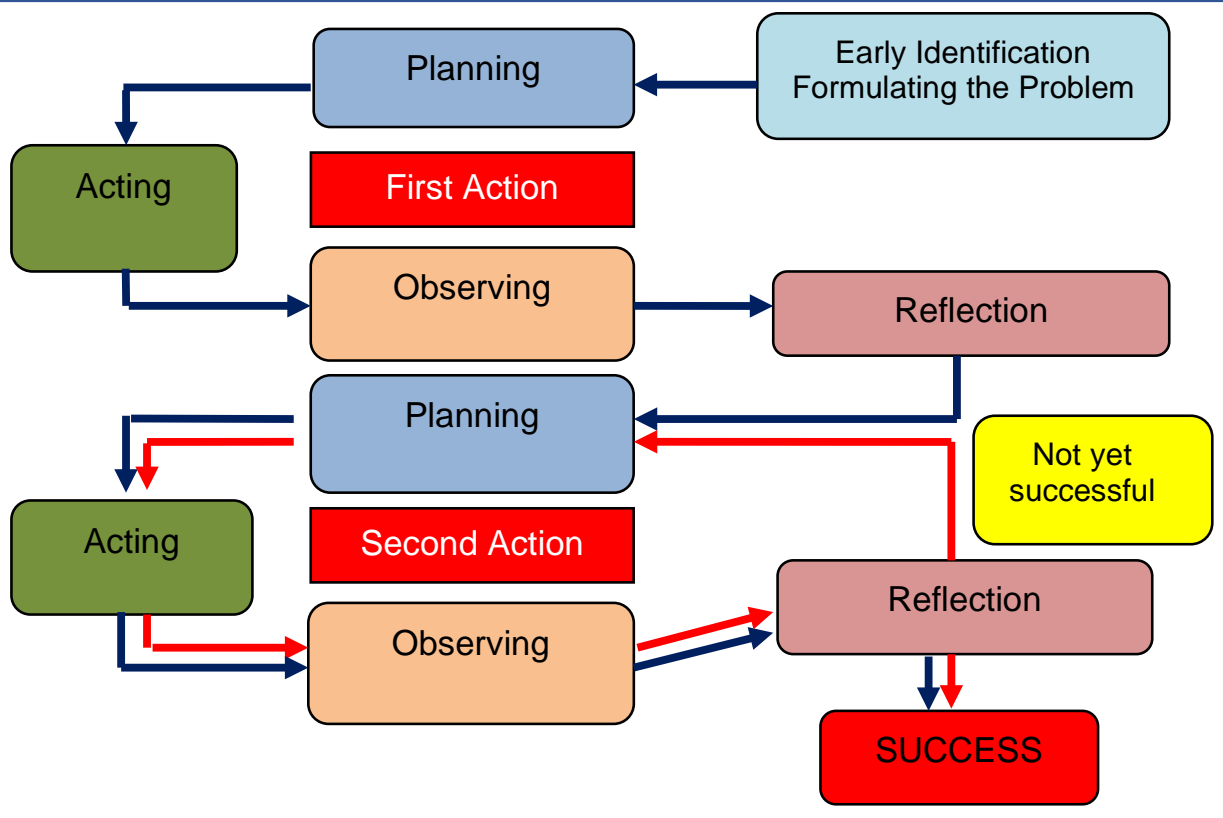

Figure 1. Classroom Action Research Flow [15]

The action research model based on Figure 2 consists of the following 4 steps:

1. Plan: What actions will be taken to improve, improve or change and attitude as a solution.

2. Action: What the counseling teacher or writer does as a desired improvement, improvement or change.

3. Observation: Observing the results or impact of actions taken or imposed on students.

4. Reflection: The author examines, sees, and considers the results or impacts of actions from various criteria. Based on the results of the author's reflection with the subject teacher, they can revise improvements to the initial plan.

This counseling guidance action research was carried out in three cycles. The three cycles are action steps which are the implementation of the mentoring plan that has been prepared by the author to determine the motivation and learning outcomes of students. Each action uses an individual guidance model with WhatsApp Group in each mentoring, each cycle is carried out 2 actions. Each cycle includes planning, implementation, action/observation and reflection.

The research subjects were class VII students of SMP Negeri 3 Ngaglik Sleman for the academic year 2020-2021 with a total of 128 students consisting of 78 women and 50 men with different ability backgrounds. The research variables that are the focus of this research study consist of three types of variables, including: 1). Input variables are variables related to students, supervising teachers, materials/materials, source of problems, evaluation procedures and the surrounding environment. 2) Process Variables, namely variables related to mentoring activities that have been designed, namely the application of individual guidance models using WhatsApp Groups to increase motivation and learning outcomes. 3) Output variables are variables related to the expected results after the research is carried out, namely increasing students' motivation and learning outcomes.

The place of research was carried out at SMP Negeri 3 Ngaglik Sleman class VII semester II for the 2020-2021 academic year which was located at Sardono Harjo Temple, Ngaglik District, Sleman Regency. The research time is carried out for 4 months starting from December to April 2021.

Data analysis was carried out throughout the study from the beginning to the end of the implementation of the action in the form of a percentage (\%), to cover the success of implementing the individual mentoring model with WhatsApp Group, on motivation and learning outcomes. Before conducting the analysis, the authors need to process all the data obtained based on observations, then look for the average (mean) value of all students. To calculate the average value of students can use the following calculation formula [16]. 


$$
\boldsymbol{X}=\frac{\sum \boldsymbol{x}(\text { Score of each student })}{n(\text { total students })} \times 100 \%
$$

\section{Information:}

$$
\begin{aligned}
\mathrm{x} & =\text { average value } \\
\sum_{N} \mathrm{x} & =\text { score } \\
& =\text { a lot of data/amount of data }
\end{aligned}
$$

The description of the class success criteria is presented in Table 1.

Table 1. Conversion of scores to class success criteria

\begin{tabular}{ccc}
\hline Value Range & Conversion & Category \\
\hline $85-100$ & A & Very Good \\
$70-84$ & B & Good \\
$55-69$ & C & Enough \\
$40-54$ & D & Not enough \\
$<40$ & E & Very less \\
\hline
\end{tabular}

\section{RESULTS AND DISCUSSION}

Before conducting the research action, the researcher first made observations on the report card documents that were used as an initial description based on the results of observations showing that the ability of students to participate in the learning process was still very lacking, most of the students who had learning outcomes in odd semesters were in the medium category with the number of 25 students, and 7 students are in the less category. The results of the initial observations can be seen in Table 2.

Table 2. The results of the initial observation of the learning outcomes document

\begin{tabular}{cccc}
\hline Value Range & $\begin{array}{c}\text { Number of } \\
\text { Students }\end{array}$ & Conversion & Category \\
\hline $85-100$ & 0 & A & Very Good \\
$70-84$ & 15 & B & Good \\
$55-69$ & 10 & C & Enough \\
$40-54$ & 7 & D & Not enough \\
$<40$ & 0 & E & Very less \\
\hline Total & 32 & & \\
\hline
\end{tabular}

Table 2 above shows that the learning outcomes of students in odd semesters are still relatively moderate. In the pandemic era students learn less motivation so that researchers encourage to solve problems by improving learning outcomes and student motivation during the Covid-19 pandemic by doing individual guidance using WhatsApp Groups for class VII/a students of SMP Negeri 3 Ngaglik, Sleman Regency.

After the students were in the mentoring activity for 3 cycles, 5 students were in the very good category, and 25 students were in the good category, and the category was enough for 2 people. Overall, the development of learning outcomes before being given action (pre-action) and after being given action for 3 cycles increased by 30 people, based on a percentage of $93.75 \%$, while in pre-action it was 10 people based on a percentage of $31.25 \%$ and at the end of cycle 3 there is an increase of 20 people based on $62.50 \%$ percent. 
Table 3. Student learning outcomes after being given guidance during cycles I, II, and III Class VII/a SMP Negeri 3 Ngaglik Sleman

\begin{tabular}{cccccc}
\hline $\begin{array}{c}\text { Value } \\
\text { Range }\end{array}$ & $\begin{array}{c}\text { Cycle } \\
\text { average I }\end{array}$ & $\begin{array}{c}\text { Cycle } \\
\text { average II }\end{array}$ & $\begin{array}{c}\text { Cycle } \\
\text { average III }\end{array}$ & Conversion & Category \\
\hline $85-100$ & 0 & 2 & 5 & A & Very Good \\
$70-84$ & 17 & 23 & 25 & B & Good \\
$55-69$ & 10 & 4 & 2 & C & Enough \\
$40-54$ & 5 & 3 & 0 & D & Not enough \\
$<40$ & 0 & 0 & 0 & E & Very less \\
\hline Total & 32 & 32 & 32 & & \\
\hline
\end{tabular}

Efforts to increase learning motivation that are developing in a better direction do not just happen because there is a process that is passed. The motives cannot be observed directly, but can be interpreted in their behavior in the form of stimulation, encouragement, or power generation [17]. The condition of students in SMP N 3 Nglik, Sleman district who do not yet have an awareness of learning motivation, is one of the supporters in increasing learning motivation.

The action in the first cycle with individual guidance using WhatsApp Group was more and more enjoyable, showing the results that most of the students' learning motivation levels were in the high category achievement of the total 32 students in class VII/a SMP Negeri 3 Ngaglik Sleman. There is a significant increase in learning motivation when compared to before the action research was carried out. Awareness made by students in receiving lessons during the pandemic through online (online) so that indirectly students make changes to better behavior increase learning motivation which has an impact on learning outcomes.

In the second cycle with the topic of the importance of guidance, it shows that class VII/a students of SMP N 3 Ngaglik Sleman have developed a level of motivation, the results of the observation score are 108 , with an average score of 2.92 , the percentage reaches $72.97 \%$ in the "Good" category. "The value of $\mathrm{B}$, when compared with the first cycle there is an increase of $16.21 \%$. An increase in the average number of learning motivation observation scores which is a reference to see the development of the overall level of learning motivation of students. In the first cycle the average score of the observation of learning motivation is 2.27, and in the second cycle is 2.92, the average score of the observation of learning motivation increases by 0.65 . In line with the results of observations made on students more active, so that it can affect the increase in students' learning motivation. In the implementation of cycle II, the researcher argues based on interviews that continuous learning is carried out online in Cycle I. In Cycle I, learning that is chosen is that online learning is fun and in Cycle II, students think that online learning during a pandemic is very important. Students are given at the end of each cycle, so that it can help researchers to continue mentoring in coordination with other teachers who are related to the task.

Cycle III action with the topic of Achieving Dreams which emphasizes efforts to improve action in cycle III there is an increase in the number of students who experience the development of the level of learning motivation, namely the total score of 128 , the percentage reaches $86.49 \%$, category "Very Good" grade $A$. The development of the level of learning motivation seen from the average number of learning motivation scores also increased compared to the second cycle. The average number of learning motivation scores in cycle II was 108 in cycle III increased to 128. If viewed as a whole from cycle I, cycle II, and cycle $\mathrm{III}$, the development of learning motivation level from the average score of learning motivation instrument in cycle III increased more than cycle III. I. It means that the research has shown the researcher's expectation with a success indicator of $85 \%$. The results of the study are seen based on Table $\mathbf{4}$ below: 
Table 4. Results of observations of students' learning motivation during cycles I, II, and III Class VII/a SMP Negeri 3 Ngaglik Sleman

\begin{tabular}{|c|c|c|c|c|}
\hline \multirow{2}{*}{ NO. } & \multirow{2}{*}{ INDICATORS / STATEMENTS } & \multicolumn{3}{|c|}{ Total score average } \\
\hline & & cycles I & cycles II & cycles III \\
\hline 1 & Persevere in the Face of Tasks online. & 19 & 23 & 29 \\
\hline 2 & Hard work in the face of adversity. & 12 & 15 & 17 \\
\hline 3 & Happy to work independently & 5 & 6 & 7 \\
\hline 4 & Not easily influenced by others. & 10 & 12 & 14 \\
\hline 5 & $\begin{array}{l}\text { Happy to Find and Solve Problems or questions online } \\
\text { (Google). }\end{array}$ & 4 & 7 & 11 \\
\hline 6 & There is a desire and desire to succeed & 9 & 12 & 13 \\
\hline 7 & $\begin{array}{l}\text { The existence of encouragement and need in online } \\
\text { learning (online). }\end{array}$ & 5 & 10 & 13 \\
\hline 8 & $\begin{array}{l}\text { There are interesting activities in online learning } \\
\text { (online). }\end{array}$ & 4 & 6 & 7 \\
\hline 9 & Conducive Learning Environment. & 16 & 17 & 17 \\
\hline & Amount & 84 & 108 & 128 \\
\hline & average score & 2,27 & 2,92 & 3,46 \\
\hline & Percent & 56,76 & 72,97 & 86,49 \\
\hline & category & Enough & Good & $\begin{array}{l}\text { Very } \\
\text { Good }\end{array}$ \\
\hline & Mark & C & B & A \\
\hline
\end{tabular}

The role of the counseling guidance teacher greatly influences efforts to increase learning motivation in students through individual guidance services. This can be seen at the time of selecting students to be research subjects. Of course, this cannot be separated from the collaboration between researchers and counseling guidance teachers as observer partners who better understand the conditions of students who will become research subjects so that researchers get an overview of the conditions of students. In addition, the role of observers assists in efforts to improve in each cycle carried out by researchers such as being an observer, providing feedback on the implementation of guidance, and providing an assessment of the entire program implemented by researchers through structured interviews.

The individual guidance model through the "WhatsApp Group" designed by the researcher is intended so that students can be actively involved and enthusiastic and motivated during the guidance process. In addition, through individual guidance services students are directed to learn from every experience during the process because it raises awareness of students to be motivated in learning. In other words, individual guidance techniques are guidance techniques given to students to find and develop themselves so that they become stable and independent individuals and are able to optimize their potential.

The following opinion will be easier to implement if there is good cooperation between the counseling guidance teacher and the homeroom teacher in providing assistance to students who have the same problem. As long as students are less aware of the importance of learning, the teachers' method of teaching is more focused on mastering the subject matter and putting aside awareness in students to generate motivation to learn. During the individual online guidance services through WhatsApp Groups provided to students, at first they seemed lazy to follow the activities, but in the end they enjoyed every process that occurred in the implementation of the guidance activities. This is inseparable from the way researchers design individual guidance service programs with a variety of varied activities so that they are more useful, more interesting, so that they are not boring, and encourage students to be actively involved. 


\section{CONCLUSION}

Based on the results of research and discussion, the researchers can conclude the following:

1. The success of students in online learning is proven by the increase in student learning outcomes in odd semesters. After individual guidance is carried out through WhatsApp Group by counseling guidance teachers.

2. The level of learning motivation of students after conducting an action research of class VII/a of SMP Negeri 3 Ngaglik Sleman for 3 cycles of development is very good. The factors that influence students' learning motivation increase in each individual mentoring cycle with WhatsApp Groups, thus making students want to learn and awareness or encouragement to learn through online increasingly increasing self-confidence.

3. The implementation of individual guidance services using WhatsApp Groups can effectively increase the learning motivation of class VII/a students of SMP N 3 Ngaglik Sleman for the 2020/2021 Academic Year. As for the supporting factors in increasing students' learning motivation, namely the suitability between the topic of guidance and the learning motivation to be improved, with individual guidance models that are packaged in a fun and varied manner in a sustainable form according to the needs of students.

\section{REFERENCES}

1. A. Ahmadi. Bimbingan dan Konseling di Sekolah. (Rineka Cipta, Jakarta, 1991)

2. W.A.F. Dewi. Edukatif: Jurnal IImu Pendidikan, 2, 1 (2020)

3. M. Daheri, Juliana, Deriwanto, A.D. Amda, Jurnal Basicedu: Journal of Elementary Education, 4, 4 (2020)

4. Jumiatmoko. Wahana Akademika. 3, 1 (2016)

5. M.A. Pribadi dan A. Benny. Media dan Teknologi dalam Pembelajaran. (Prenada media Group, Jakarta, 2017)

6. Anwar dan Riadi. Jurnal IImu Teknik elektro Kompuer Dan Informatika. 3, 1. 2-10. (2017)

7. Suryadi, dkk. Jurnal Pendidikan Islam. 7, 1, 1-22 (2018).

8. Sidiq. Jurnal Putri Hijau, 4, 2, 145-154 (2019).

9. F. Rosarians, A. Warsono, A. Fikri, and S. Permana (2020, March 16). Belajar di Rumah.Lewat WhatsApp. https://koran.tempo.co/read/metro/451002/belajar-di-rumah-lewat-WhatsApp? (Retrieved January 15, 2021).

10. Pranajaya and H. Wicaksono, Orbith, 14, 1, 59-67 (2018)

11. P.A. Prawira, Psikologi Pendidikan dalam Perspektif Baru,(Ar_Ruzz Media, Jogjakarta, 2013), pp. 319

12. H. Uno, Teori Motivasi dan Pengukurannya. (PT Bumi Aksara Bandung, Jakarta, 2011)

13. Winkel. Psikologi Pengajaran. (Grasindo, Jakarta, 2005)

14. A.M. Sardiman, Interaksi dan Motivasi Belajar Mengajar. (Rajawali Pers, Bandung, 2007)

15. A. Susanto. Teori Belajar dan Pembelajaran di Sekolah Dasar. (Kencana Prenadamedia Group, Jakarta, 2013)

16. Sugiyono, Metodologi Penelitian Bisnis, (PT. Gramedia, Jakarta, 2007)

17. A.S. Makmun, Psikologi Kependidikan (Remaja Rosdakarya, Bandung, 2007) 